\title{
Correction to: Monitoring changes in malaria epidemiology and effectiveness of interventions in Ethiopia and Uganda: Beyond Garki Project baseline survey
}

Tarekegn A. Abeku ${ }^{1 *}\left(0\right.$, Michelle E. H. Helinski ${ }^{1,3}$, Matthew J. Kirby ${ }^{1,7}$, Takele Kefyalew ${ }^{2}$, Tessema Awano ${ }^{2}$, Esey Batisso ${ }^{2}$, Gezahegn Tesfaye ${ }^{2}$, James Ssekitooleko ${ }^{3}$, Sarala Nicholas ${ }^{1}$, Laura Erdmanis ${ }^{1,4}$, Angela Nalwoga ${ }^{5}$, Chris Bass ${ }^{4}$, Stephen Cose ${ }^{5,7}$, Ashenafi Assefa ${ }^{8}$, Zelalem Kebede ${ }^{2}$, Tedila Habte ${ }^{2,6}$, Vincent Katamba ${ }^{9}$, Anthony Nuwa ${ }^{3}$, Stella Bakeera-Ssali ${ }^{3}$, Sarah C. Akiror ${ }^{3}$, Irene Kyomuhangi ${ }^{3}$, Agonafer Tekalegne ${ }^{2}$, Godfrey Magumba ${ }^{3}$ and Sylvia R. Meek

\section{Correction to: Malar J (2015) 14:337}

https://doi.org/10.1186/s12936-015-0852-7

Please be advised that one of the author names is incorrectly spelled in the published article: 'Irene Kyomuhagi' should be 'Irene Kyomuhangi'.

The corrected name can be found in the author list of this article.
Assefa A, Kebede Z, Habte T, Katamba V, Nuwa A, Bakeera-Ssali S, Akiror SC, Kyomuhangi I, Tekalegne A, Magumba G, Meek SR. Monitoring changes in malaria epidemiology and effectiveness of interventions in Ethiopia and Uganda: beyond Garki Project baseline survey. Malar J. 2015;14:337. https://doi.org/10.1186/s12936-015-0852-7.

\section{Publisher's Note}

Springer Nature remains neutral with regard to jurisdictional claims in published maps and institutional affiliations.

\begin{abstract}
Author details
${ }^{1}$ Malaria Consortium, London, UK. ${ }^{2}$ Malaria Consortium, Addis Ababa, Ethiopia. ${ }^{3}$ Malaria Consortium, Kampala, Uganda. ${ }^{4}$ Rothamsted Research, Harpenden, UK. ${ }^{5}$ Medical Research Counci//Uganda Virus Research Institute, Uganda Research Unit on AIDS, Entebbe, Uganda. ${ }^{6}$ South Nations, Nationalities and Peoples Regional Health Bureaux, Hawassa, Ethiopia. ${ }^{7}$ London School of Hygiene \& Tropical Medicine, London, UK. ${ }^{8}$ Ethiopian Public Health Institute, Addis Ababa, Ethiopia. ${ }^{9}$ National Malaria Control Programme, Ministry of Health, Kampala, Uganda.
\end{abstract}

Published online: 25 November 2019

\section{Reference \\ 1. Abeku TA, Helinski MEH, Kirby MJ, Kefyalew T, Awano T, Batisso E, Tesfaye G, Ssekitooleko J, Nicholas S, Erdmanis L, Nalwoga A, Bass C, Cose S,}

The original article can be found online at https://doi.org/10.1186/s1293 6-015-0852-7.

*Correspondence: t.abeku@malariaconsortium.org

${ }^{1}$ Malaria Consortium, London, UK

Full list of author information is available at the end of the article

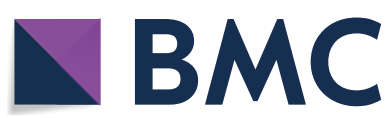

(c) The Author(s) 2019. This article is distributed under the terms of the Creative Commons Attribution 4.0 International License (http://creativecommons.org/licenses/by/4.0/), which permits unrestricted use, distribution, and reproduction in any medium, provided you give appropriate credit to the original author(s) and the source, provide a link to the Creative Commons license, and indicate if changes were made. The Creative Commons Public Domain Dedication waiver (http://creativecommons.org/ publicdomain/zero/1.0/) applies to the data made available in this article, unless otherwise stated. 